ルが筆者のもとで設計・試作中である.

\title{
4. 抽出した構造データにもとづく計算処理
}

このデータファイルには格子定数や原子座標なぞの基礎データが収められているので，これらを取出 して適当なプログラムに入力すれば, 原子間距離・結台角の計算や投影図作成その他種々の結晶計算が できて大変便利である．ただ，XDATA から取出されたデータは普通プリントアウトに出るので，こ れをカードにパンチして入力するのでは仕事が 2 段階にならざるをえない. 取出したデータを直ちに次 のステップに受継いで種々の計算ができれば大変好都合であるが，このためのプログラムが岩崎集氏の ところでほぼ出来上がったもようである。

\section{5. あとがき}

このファイルは結晶構造を専門としない方々によっても大変有用に違いないと考えられるが，ただ上 記からも察せられるように, これを使いやすくするにはまだ為すべきことが多いので, 有志の方々の積 極的な御協力, 御批判を期待している.

スペースの関係もあってファイル自体の説明が簡略にすぎたきらいがあるが，詳細は文献 2 )，3)を 参照されたい。

\section{参考文献}

1) 大崎健次 : 日本結晶学会誌 16, 244 (1974)

2）島内武彦，山本毅雄：“結晶構造データ上その検索”。文部省科学研究費による特定研究「広域 大量情報の高次処理」, 開発 C班（昭和50年 4 月）

3）大崎健次 : “Cambridge Crystallographic Data File と日本におけるその利用について”（昭和 48年10月). 非公式文書ですが御希望の方にはコピーをお送りします

日本結晶学会誌 17, 297 (1975)

\section{欧州中性子回折雑感}

\section{平川金四郎*}

昨年10月中旬から年末まで Grenobe の Laue-Langevin 研究所 (ILL) において, 中性子回折実験を 行なら機会が与えられたが，その間 München, Berlin, Jülich, Sacley 等の原子炉を持つ研究所を訪問 する機会もえられたので私の見てまわった範囲での見聞記としたい。

そもそも米国と欧州とでは研究態度も違い，中性子回折の面においても，米国は current problem に 焦点を合わせるべく，最高の性態の装置を揃え技術をみがき上げている，具体的にいらと，大体 3 軸型 の分光器を主体として用いており, phonon, magnon 等の結晶を舞台とした素励起の研究について, 最 高のレベルにあるといえるし，またこの方法が見出され活用されたことが，将に時流に乗ったともい充 るであろ5。しかし欧州では別の行き方をしたようにみえる.どこの原子炉をのぞいても，3つも4つ も3 軸型を持っているところはまずない. 物性研究の current topics を追らのには，とてもすぐには使 えないような異色の装置が多い.とくにドイッではそうである.そして ILL の究研所は先の展望を考 えて，まさにこれら異色の装置の長所を取り上げた集大成の産物であるといってよかろう. Guide 管の 活用などはまさにその典型である，従って ILL の中味を紹介すれば, おおよその動向は分かるといっ てもよい. しかし ILL 以外の研究所をまわってみると, そこに若干の面白い相異がみられる.このこ とはあとで述べるとして，ILL について話しておこう．ILL の装置の内容はもういくつか報告されて

\section{* 東京大学物性研究所}


いるので, 詳しくはふれないが, 研究所は専属, 外来の研究者（半々）を含めて, 150 名近く, その内 $1 / 3$ が物性, $1 / 3$ が核物理, $1 / 3$ がポリマーである. 実駼装置は3〜40台あって, いずれも素晴らしい性 能をもつものである. その種類もまことに多様で, 共同利用の研究所にふさわしく, どんな測定でも受 付けます……といた感じである．共用利用といら面に特に力を入れているのも米国とは対照的である。 しからば欧州の ILL 以外の研究所はどうであろらか?.手近かな所に性能の優れだ装置があるし, 誰 でも申し込める……となると, そのような衛星研究所は存在意義を失ならであろらか?……これはひと ごとではない. 日本だって同じ立場にある.しかしここに問題がある. 文切り型の高性能装置があるだ けで本当にいい研究が生まれるであろらか。少々性能はおちても, 自分の手塩にかけた装置を自分の idea で思うままに改造してこそ新しいニニークな成果が生ま礼るのではなかららか. 恐らく多くの衛星 研究所に働く人々の間にはこらいった意識があるのだろうと思った。また予備的な研究はやっておかな いと ILLは寸ぐには使えないといらこともあろう．2つの例をあげょう．1つは最近 ILLで測定をこ ころみられた $\mathrm{He}^{3}$ の励起スペクトルの測定である. $\mathrm{He}^{3}$ の励起は誰もどんなものか知りたいのは当然 で，実際米国で測定をこころみられたが，何せ $\mathrm{Cd}$ 並に吸収の大きい $\mathrm{He}^{3}$ の測定はとても成功どころ ではなかった． ILLで Scherm らは low energy nentron の強い flux と low background に物をいわ せて測定し, とも角F Fermi 粒子特有のパタンを見たし, さらに roton like excitation の有無を追跡し ようとしている。これはまさにILLでなければ出来ない仕事である。もう1つの例で面白いと思った のは, Sacley で Abragam 一派のやっている核偏極したターゲットが入射中性子に対して作る Pseudomegnetic field の唡証実験である.この field の中を通過する中性子のスピンの碰気共鳴をみている. 炉の中には大きい断熱消碰用のマグネットやマイクロ波回路がもちこまれュニークな研究が進められて いる、これは私の興味をかなりひいたもので，このことをILLに㷌って話したら，その人日く，「彼 はノーベル賞でも权らっているのだろう，俺たちのところは共同利用の研究所だ。あんな勝手なことは 出来ない」と.

これらのことは我々にも考えさせら机るところがある。こ絃ら日本で新しい原子炉をもつ場台，こ の 2 面の特質をうまく生かし調和させてもらいたいものである．また ILL に期待をかけすぎないよう にすることも大切だと思う. いかに伢の性能がよくても, 目的とする研究に対し角度駆動の精度が一桁 悪くても,クライオスタットの温度制御がちょっと悪くても, データはアウトになることがある. やは り手許で愛しみ育てた装置には棄てがたいものがある。また所詮研究目標の立て方や idea が新しい研 究を生むことを思えば，炬の性能は若干おちても，そこに日本の活路を見出すべきであろら，とはいえ 与えられた予算の枠で, bestなものを作ることは我々の使命であり, これには理学, 工学, その他の関 係者の間に密接な連絡と協力があってこそ始めて実現すると思われる.

ILL で私にあてがわれた部屋は高分子（生体）の Dr. Haasとスピンェコー法で有名になった Dr. Mezei と同居のものであった．生体高分子のように木に竹をついだような専門の違ら人と一緒にさせら れてはかなわん……最初は思ったが, 実はこれがいい勉強になった。彼のテーマはアポフェリチンと いら生物蛋白の中に含まれるHの重水素置換のプロ七スを追ら化学反応の実験である．この分子は 1000

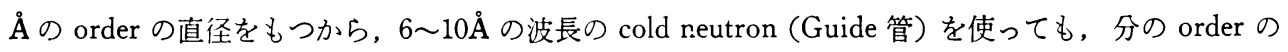
幅をもつ小角散乱として観測される．この種の実験では蛋白高分子の1つを 1 個の原子のようにみなし て, その form factor を測ることといってもよい. 散乱長は溶質と溶媒との散乱長のコントラストによ ってきまる. 実験では $2 \%$ の蛋白分子と $18 \%$ の水からなる液(A) $80 \%$ の重水®とを瞬時にまぜ, その直 後から form factor の時間的変化を測り, どのような部分から $\mathrm{H} \rightarrow \mathrm{D}$ の置換が進むかが分かる. 散乱ビ 一ムは $64 \times 64$ コのエレメント $\left(1\right.$ つは $\left.1 \mathrm{~cm}^{2}\right)$ をもつ 2 次元カウンターでうける（現在 $128 \times 128$ に改 造中). 干涉性散乱が物凄く強くなる (incident beam が強いためではない) ので, 殆んど瞬間撮影がで き，1秒の時定数をもつ変容が追えるとのことである．この分子には中にパイプで通ずる空洞があって， 空洞内の $\mathrm{H}$ と D と置換は，このパイプを通じてなされるのであるが，溶液に蔗糖を入れておくと，そ のような分子はパイプを通りにくいので，変容の時定数が変わる．それからパイプの太さを出すといら

17. 5-44 
のである.この種の実験はふつら数分で測定が終わる. マンンタイムは 1 〜日もらうのが通例で, お 前たちのように 1 週間も 2 週間ももらったらデータ整理に音を上げるワと笑っていた．水の中に $2 \% し$ か分子を含まないよらな回折は非干涉性項のため,これまでの常識では考えてもみられなかったことで ある．実際私も㷌国後直ちに高分子の代わりに微粒子に対してこの方法を応用し，表面の異常を䓎い中 性子源でみることが出来た。

この実験のまさに反対を行くのが背面反射法で, 当り前のことではあるが, 格子定数の精密測定とか, 緩和時間の特に長いもの（１0-8 sec の order）の測定に使える. また $150 \mathrm{~m}$ も飛ばすよらな長い Guidel 管でこの方法と TOF とを併用すれば，格子常数の超精密測定ができるわけで，このような例が Jülich や München にみられる.それだけに強度のガタオチは覚悟せ权ばならない.このよらにちょっとconventional な使い方を変えただけでも，新しい分野の開拓にとって貴重な他山の石となりらるドイッ で多く作られたこのような変わり物の中には，結局日の目をみないで終わるものもあろう。しかし新し い研究テーマに有効に活用されたら恐ろしいことである.

私は今回欧州を訪れて，研究テーマの選択に関して，随分保守的(?)な（別にそれが悪いとはいわな いが）友人が多いのに驚いた。しかし話をしている間に，チラホラ中性子のもっと違った使い方や意表 をつくテーマを虎視盹々と杨らっている 1〜2の人をかいまみた. 新しいテーマと，それにマッチする 中性子の使い方の雨面を的確に見抜くこと, これは今後の日本の進展をきめる大きな要素となると思う. 浮き上がっては困るが, 若い方々の間で真剣に考えてもらいたいものである、同室の Mezei はまだ大 変若い. 彼は装置のみではなく, 新しい物理的問題に常に目をひからせており,つまらない話には見む きもしない，クリスマスが近づくと皆浮き足立って我が家へとむかった。彼も私も独身者(?)というの でグルノーブルの山奥のレストランに 1 日中入りびたって大いに気焰を上げた。窒の壁には彼が手書き した次の一文がはってある，あれは面白いネといったら彼は黙って笑っていた。

If government laboratories had been operated in the stone age, we shold have wonderful stone axes. But no one would have discovered metals.

Sir. J. J. Thomson.

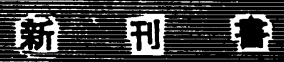

\section{O. Muller and R. Roy}

\section{The Major Ternary Structural Families}

(Springer-Verlag Berlin Heidelberg

New York, 1974 pp487, 図 46, US \$29.30)

本書は材料科学の大学院生や材料を実際に研究・開発している人々を対象として書かれた, R. Roy 編集のシリーズ : Crystal Chemistry of Non-Metallic Materials の中の第 4 巻である. 本書は結晶学的 に異なる 2 種類の陽イオン席と 1 種類の陰イオン席を有する化合物を結晶化学の立場から取り扱ってお り, General Electric Co. の O. Muller と Pennsylvania State University の R. Roy の共著である. 本書の内容は次のようである.

I 伃論

II $\mathrm{A}_{2} \mathrm{BX}$ 型構造: $\mathrm{K}_{2} \mathrm{NiF}_{4}, \beta-\mathrm{K}_{2} \mathrm{SO}_{4}$, olivine $\left(\mathrm{Mg}_{2} \mathrm{SiO}_{4}\right)$, spinel $\left(\mathrm{MgAl}_{2} \mathrm{O}_{4}\right), \mathrm{CaFe}_{2} \mathrm{O}_{4}$, phenacite $\left(\mathrm{Be}_{2} \mathrm{SiO}_{4}\right)$ など

III $\mathrm{AB} \mathrm{X}$ 型構造 : zircon $\left(\mathrm{ZrSiO}_{4}\right)$, scheelite $\left(\mathrm{CaWO}_{4}\right)$, baryte $\left(\mathrm{BaSO}_{4}\right)$, ordered $\mathrm{SiO}_{2}$ derivatives など 